\title{
INKLUSIVISME EN EKSKLUSIVISME: 'N STUDIE VAN TWEE TENDENSE
}

Author:

Pieter M. Venter

\section{Affiliation:}

${ }^{1}$ Departement Ou-

Testamentiese Wetenskap,

Universiteit van Pretoria,

Suid-Afrika

\section{Correspondence to:}

Pieter M. Venter

e-mail:

pm.venter@up.ac.za

\section{Postal address:}

Departement $\mathrm{Ou}$ -

Testamentiese Wetenskap,

Fakulteit Teologie,

Universiteit van Pretoria

Lynnwoodweg, Hatfield

0083, Suid-Afrika

\section{Keywords:}

Van Ruler;

multikulturalisme;

religieus-kulturele

pluralisme; apostolaat;

teokratiese teologie

\section{Dates:}

Received: 10 July 2009

Accepted: 11 Sept. 2009

Published: 06 Nov. 2009

How to cite this article: Venter, P.M., 2009

'Inklusivisme en eksklusivisme: ' $n$ Studie van twee tendense', HTS Teologiese Studies/ Theological Studies 65(1), Art. \#314, 10 pages. DOI: 10.4102/hts.v65i1.314

This article is available at:

http://www.hts.org.za
(C) 2009. The Authors. Licensee: OpenJournals Publishing. This work is licensed under the Creative Commons Attribution License.

\section{ABSTRACT}

Inclusivism and exclusivism: A study of two trends

The identity of the church can be either inclusivist or exclusivist. Van Ruler's theocratic theology views the church as being an inclusive community in service of God's kingdom. It is the vehicle God uses to introduce his kingdom into the world. According to Van Ruler, however, the church also shows a unique character based on its relationship with Jesus Christ. Although the church can take many forms, Van Ruler's opinion is that the Christian Church could be advised by Old Testament Israel in this regard. This study shows that both inclusivist and exclusivist trends are present in the Old as well as the New Testament. The New Testament inherited the debate between these two opposing stances from the time of the Second Temple. Returning from exile, Sadocitic priests propagated an exclusivist identity for the Judaeans. Their viewpoint was based on the programme of Ezekiel 40-48, as is illustrated in the literature of Ezra-Nehemiah, the Priestly Writing, Chronicles and Jubilees. On the other hand, indeed there was an inclusivist approach as well, as is depicted in the books of Jonah, Ruth, Trito-Isaiah and even Numbers and Joshua. The conclusion drawn from the study is that both exclusivist and inclusivist trends are present in the Bible. Although the church does not have any other option in the present postmodern world but to be primarily an inclusive community, it should also show some form of exclusivism.

\section{INLEIDING}

In 'n besinning oor die aard van die Christelike Kerk, kan die konteks waarin die kerk bestaan nie geïgnoreer word nie. Vir geruime tyd het die klem hoofsaaklik op die eksklusiwiteit van die kerk geval, ten koste van die dringende behoefte om ook inklusief te wees. Die wêreld beweeg egter tans ál verder weg van eksklusiewe gemeenskappe. Kulturele imperialisme het ook in die postmoderne tyd in onguns verval. Daarmee saam het die aanspraak op die universele geldigheid van die Christendom, en die gevolglike houding van triomfalisme en eksklusivisme, ál meer onder kritiek begin deurloop. Die era van 'n dominante Christendom het stelselmatig oorbeweeg na 'n pluralistiese wêreld, waarin geen religie meer op die eksklusiewe bevoorregte posisie van dié universele geloof kan aanspraak maak nie.

Hierdie beweging noop die kerk om opnuut te besin oor sy posisie in die wêreld, en oor die vorm wat dit in hierdie wêreld aanneem. Dit behels sake soos die apostolaat van die kerk, en sy sendingbedrywighede in die wêreld. Dít bring op sy beurt die vraag na inklusivisme en die houding teenoor die 'ander' ál meer op die voorgrond (kyk Park 2003:79-80). In 'n tyd van multikulturalisme en religieus-kulturele pluralisme, het die kerk volgens Park (2003:5) voor die uitdaging te staan gekom:

...[h]ow Christians can maintain integrity while they affirm their mission to witness to God's grace through Christ to the world and at the same time to genuinely embrace the reality of God's freedom to dispense grace to whomever God wishes and in whatever way God chooses.

In die huidige tydsgewrig het dit dus noodsaaklik geword om oor die kerk se identiteit te besin in terme van die begrippe 'inklusivisme' en 'eksklusivisme'. Hierdie artikel gaan vervolgens op hierdie twee sake in.

\section{VAN RULER AS AANKNOPINGSPUNT}

Naas die Bybel, kan die kerk ook ander bronne ontgin om oor sy identiteit, en dus ook oor sy apostolaat en missionaat, te besin. Een van hierdie bronne is die Nederlandse teoloog Arnold Albert van Ruler (1908-1970). Sy werk is om twee redes belangrik vir hierdie studie.

Eerstens het hy sy apostolaatsteologie ontwikkel in 'n era toe Europa reeds na 'n post-Christelike gemeenskap begin oorbeweeg het, waarin die Christendom sy unieke posisie moes begin prysgee. Van Ruler se siening van die apostolaat het tot uiting gekom in Artikel VIII van die destydse Kerkorde van die vroeëre Nederlandse Hervormde Kerk van 1951. Hoewel hierdie Kerkorde sedertdien deur 'n nuwer weergawe vervang is, bly sy apostolaatsteologie en algemene teologiese sienings steeds ter sake in die groter teologiese debat in Nederland, sowel as hier ter plaatse.

Die tweede rede hoekom Van Ruler belangrik is vir hierdie studie, is die voortgaande invloed wat sy teologie op navorsing het. Dít blyk duidelik uit die simposium wat in Mei 1995 in Utrecht, Nederland, gehou is - 25 jaar ná Van Ruler se dood - om opnuut belangstelling te wek vir sy werk as een van Nederland se grootste teoloë. Vir die doel van hierdie ondersoek is dit ook opvallend dat die oorgrote meerderheid van die gepubliseerde simposiumreferate onder redaksie van Gerrit Klein en Dick Steenks (1995) aan Van Ruler se beskouing oor die apostolaat gewy is.

Om Van Ruler se beskouing oor die apostolaat te beoordeel, moet dit egter teen die breër agtergrond van sy teokratiese siening begryp word. Dié artikel sal dus eerstens poog om Van Ruler se apostolaatsbeskouing uit die beskikbare literatuur te verwoord, en dit in die groter raamwerk van sy siening oor teokrasie te verstaan. Tweedens sal die artikel konsentreer op die manier waarop Van Ruler die Bybel, en veral die Ou Testament, aangewend het om tot sy apostolaatsbeskouing te kom. Oor die algemeen sien Van Ruler 
die identiteit van die Christelike Kerk as in wese inklusief. Hy lê gevolglik klem op die inklusiewe tendense van die Bybel, maar wys ook op die belang wat die Ou Testament vir die huidige gestalte van die Christelike Kerk het. In die lig daarvan dat die Ou Testament egter ook opsigtelik eksklusiewe standpunte voorhou, word daar in ' $n$ volgende gedeelte verder ingegaan op sowel die inklusiewe as die eksklusiewe tendense wat in die Nuwe Testament, maar veral ook die Ou Testament, voorkom. Ter samevatting wys die artikel laastens op die bydrae wat hierdie ondersoek na Van Ruler se apostolaatsteologie en die eksklusiewe-inklusiewe debat in die Ou Testament, tot die kerk se besinning oor sy identiteit en sy apostolaat kan lewer. Alles kom dus neer op Park se vraag: Hoe kan die Christelike Kerk sy unieke identiteit handhaaf, terwyl dit tegelykertyd van God se genade getuig wat op die hele mensdom gerig is?

\section{VAN RULER SE MISSIONALE SIENING}

Van Ruler het sy gedagtes oor die apostolaat in debat met Hoekendijk, Kraemer en Van Leeuwen ontwikkel. In sy Theologie van het Apostolaat (1953) bekyk hy die saak vanuit'n eskatologiese, predestinatiewe, pneumatologiese en antropologiese hoek. Vir Van Ruler (1953:15) is sending '...de proclamatie van het rijk van God als rijk van Christus in elk nieuw volk en in elke nieuwe tijd'. Dit gaan egter om méér as net die evangelie van Jesus Christus. Die ryk van God is baie omvattender. God is besig met die héle wêreld. Dit gaan om sy rykshandeling met die ganse wêreld. God se ryk loop met spronge deur die geskiedenis van die wêreld. Dit toon verskillende gestaltes. 'Daarom,' sê Van Ruler (1953:16-17), 'gaan haar ook de ogen open voor de betekenis van het Oude Testament, achter en rondom het Nieuwe Testament, en voor het volk Israel, de synagoge en de staat in Palestina - alle ook momenten en gestalten in Gods rijkshandelen met de wêreld.' Die apostolaat geskied dus binne hierdie groter struktuur.

In die opmars van God se ryk, is die kerk gepredestineer, om die instrument te wees in God se omgang met die wêreld. Die kerk pas in binne God se plan met die wêreld. As kerk van die Woord en as liturgiese gemeenskap, is die kerk instrumenteel vir God se uitbreiding van sy ryk. Soos Van Ruler (1953:24) dit stel:

De kerk, de christen, de zending is nooit meer dan het karretje, het vehiculum, waarop het Woord van God - het geschreven, het kanonieke, het israëlietische Woord - zich voortbeweegt van de ene mens naar de andere, van de ene tijd naar de andere, van het ene volk naar het andere.

(Van Ruler 1953:24)

Die kerk is opgeroep vir diens op dieselfde manier as wat 'Jezus Christus zelfs in zijn heersen alleen maar dienaar is en dat de kerk er alleen is terwille van de wêreld' (Van Ruler 1953:32). Soos Plaisier (1995:80) dit stel, word daar hier bedoel diens aan die ryk met die gebruik van die evangelie, en nie diens aan die wêreld vanuit die evangelie nie. Daarin sien Van Ruler dan ook die wesenskenmerk van die apostolaat. Die apostolaat was vir hom ' $n$ integrale deel van kerkwees, van die doelwit af weer teruggekyk, is 'het apostolaat haar wezen' (Van Ruler 1953:20). Die apostolaat is soos gis wat alle werksaamhede van die kerklike lewe deursuur.

Pneumatologies en antropologies beskou, is die implikasie dat God se vreemde Woord deur die Gees so in die mens se bestaan geïnternaliseer word, dat die Woord deur die Gees eintlik die mens se 'geweten, de con-sciëntie, het mede-weten en medeoordelen met God' (Van Ruler 1953:24) word. Omdat God met sy ryk op 'de grote strijd der volkeren om een politieke, sociale, economische en culturele vormgeving van het leven' inspeel (Van Ruler 1953:20), behels dit, uit ' $n$ antropologiese hoek beskou, dat die werk van die Gees in die ervaring van die mens gestalte kry. Die heil moet in gewone bestaan omgesit word... God se ryk moet in die konkrete bestaan van individu en die gemeenskap ' $n$ werklikheid word. Wanneer die Bybel in die harte van mense weerklank vind, en hulle dit in vryheid en selfstandigheid hulle eie maak, gebeur daar iets. Daar ontstaan 'n tradisie. Dít verteenwoordig ' $\mathrm{n}$ volgende sprong in die voortgang van God se ryk in die wêreld.

Só het God se teenwoordigheid sigbaar geword in die volk Israel, en het dit uiteindelik sy hoogste vorm in die lewe en die werk van Christus bereik. Daarna kry dit egter herhaaldelik konkreet historiese gestalte. Plaisier (1995:80-81) verwoord Van Ruler se gedagte soos volg: ' Het Woord van God schept culturen. De Geest vormt allerlei gestalten van het rijk, zoals de kerk, de staat en de bevinding.' Volgens Van Ruler (1953) beteken dit dat daar deur die apostolaat:

...[t]elkens nieuwe vormen van christendom ontstaan, dat de jonge kerken hun eigen belijdenissen zullen moeten hebben, dat de catholiciteit der kerk o.a. ook haar nationale karakter insluit, dat er in deze zin gesproken zal moeten worden van een pluriformiteit der kerk in de volkeren, landen en continentenen van de relativiteit, het historische karakter en het realiteitsgehalte van de waarheid: een abstracte, absolute waarheid is er niet; er is alleen het handelen en het spreken Gods en dat wordt telkens nieuw en telkens anders beleefd.

(Van Ruler 1953:40)

Van Ruler (1953:46) is oortuig dat die apostolaat van die kerk met God se waarheid te doen het, wat na 'alle dingen van het individuele en gemeenschappelijke aardse menszijn in de tijd' moet deurwerk. Soos Plaisier (1995:78) dit opsom, is die missionale taak van die gemeente 'niet alleen de bekering van individuen..., maar dat het gehele leven en de hele samenleving het object van de zending is'. Die wet en die profete van die Ou Testament toon dat die lewende God in die samelewing van mense belangstel. Hy wil sy ryk in die totale lewe oprig, met al sy sosiale, ekonomiese, sedelike, juridiese, kulturele en politieke aspekte (kyk Van Ruler 1953:45). Van Ruler (1953:45-46) is van mening dat

wat in het apostolaat aan inrichting van de samenleving wordt bereikt, niet te waarderen [zijn] als toevallig bijproduct van de prediking van het evangelie, maar behoort het op essentiële wijze tot de scopus van het apostolaat als zodanig.

(Van Ruler 1953:45)

Gevolglik som Plaisier (1995:79) Van Ruler se ekklesiologie só op: 'Het is echter duidelijk: de verkondiging van de kerk geschiedt midden in de wereld, zij is een bij uitstek open gemeenschap.'

Plaisier (1995:84) vat die betekenis van Van Ruler se apostolaatsteologie soos volg saam: 'Hij heeft velen de ogen geopend voor datgene waarvoor de kerk dient te staan: een vanzelfsprekende missionnaire dienst.' Jongeneel (1995:91) voeg daarby die waardering dat Van Ruler se apostolaatsteologie ook op die kerstening van die kultuur gerig is. Die corpus christianum het immers ook ' $n$ kultuuropdrag. In die lig van die namoderne beweging na pluralisme en veelvolkigheid, wys Jongeneel daarop dat Van Ruler se apostolaatsteologie egter nie vir 'n nie-Christelike wêreld en 'n situasie waar die kerk as 'n minderheidgroep in die diaspora funksioneer, voorsiening maak nie. Volgens Jongeneel (1995:85-94) bedryf Van Ruler ook 'n Eurosentriese apostolaat.

In sy opstel oor De kerk is ook doel in zichzelf, geskryf in 1966 hanteer Van Ruler (1978:53-66) die vraagstuk van die wêreld en die kerk se plek daarin. Hy huldig steeds sy siening dat die kerk instrumenteel is in die uitbreiding van God se ryk, maar omdat die ryk in die wêreld bestaan, is daar ook 'n kenmerkende wêreldsheid en eiesoortigheid aan die kerk. Vir Van Ruler (1978:55) gaan dit volgens die 'christelijk-israëlitisch' tendens van die kerk daarom om ' $n$ instrument te wees in die uiteindelike verlossing van die wêreld, sodat die wêreld uiteindelik homself kan wees voor die Drie-enige God. Die volk van Israel in sy uitverkiesdheidheid, die Ou Testament met sy wet en profesie, Christus en sy werk in die historiese werklikheid, die uitgestorte Heilige Gees en sy voortdurende inwoning, die gang van die apostoliese woord deur volkere en lande, die tradisie in sy duisendvoudige verskeidenheid, én die kerstende en 
Israelitiserende invloed van die kerk in die openbare lewe van staat en samelewing - voormelde is alles steeds instrumenteel in hierdie eskatologiese beweging (kyk Van Ruler 1978:55-56).

Die verlossing wat in Jesus Christus ontvang is, moet verwerklik word; moet 'omgezet worden in menselijke, geleefde levenswerklijkheid' (Van Ruler 1978:57). Die lewenswerklike gestalte wat die kerk as instrument in die wêreld aanneem, word 'steeds gemarkeerd door de bijzonderheid van het apparaat van de verlossing' (Van Ruler 1978:57). Dit gaan dus nie om die menslike in die kerk of die wêreldlikheid op sigself nie, maar om konkreet in die wêreldlike konteks 'n instrument van die verlossing te wees, en om aan die hand van die verlossing wat die kerk ontvang het, 'n identiteit te ontwikkel. Die kerk moet steeds sy vaste punt in die persoon en werk van Jesus Christus hê, maar moet van daar sy identiteit in menslike vorm vind.

Wat vorm betref, het die kerk ook ' $n$ institusionele karakter, maar een wat in wezen verwikkeld blijven in de apostolische traditie waarin de representatie, de tegenwoordig-stelling van het heil geschiedt' (Van Ruler 1978:57). Die saak wat die kerk in die wêreld verteenwoordig - die heil in die wêreld - bring onvermydelik mee dat die kerk ook as instituut funksioneer (kyk Van Ruler 1978:58). Die kerk staan van nature veranker in die tradisie. Die kerk is ' $n$ moment of ' $n$ gestalte van die verloop van die apostoliese woord deur die wêreld. Die beeld wat Van Ruler (1978:58) gebruik, is dat die kerk 'een tent op de kermis van de leven' is. Dit is ' $n$ eiesoortige tent naas baie ander tente in die wêreld. In daardie tent is egter iets te belewe wat nêrens elders beleef kan word nie, naamlik die heil en die verlossing.

Terwyl die kerk as apostoliese instituut dus geen doel op homself is nie, net daar is ter wille van homself nie, maar in diens staan van sy apostoliese opdrag, het dit tog 'n eie unieke gestalte. 'De gestaltelijkheid van Jezus is door de Geest vertolkt in een stem, de stem van de apostolische boodschap en de institutaire kerk is in haar gestaltelijkheid draagster van deze boodschap' (Van Ruler 1978:59).

Teen die agtergrond van die uiteensetting hier bo, maak Van Ruler (1978:60) dus die stelling 'dat de kerk óók doel in zichzelf is'. Die kerk kán en móét ook homself wees. Hy moet 'n selfstandige faktor wees met sy eie aansprake, selfs moontlik met sy eie mag, en met 'n eie gesag in die openbare lewe (kyk Van Ruler 1978:65). Deur sy lede se belydenis, hulle himnologiese aktiwiteite en hulle liturgiese belewenis van die eenheid met Christus, toon die kerk ook ' $n$ eiesoortigheid wat binnekerklik gerig is. Volgens Van Ruler (1978:65) is die idee van belangelose diens in en aan die wêreld eenvoudig ontoereikend om volledig uitdrukking te gee aan die wese van die kerk en sy funksie in die wêreld. Die teenweer teen 'n beskouing wat die kerk slegs in die lig van die apostolaat sien, is om die kerk, aan die hand van wat hier uiteengesit is, ook as ' $n$ doel op sigself te beskou. Die geheel van die ryk van God en sy gang deur die wêreld spel die besondere karakter van die kerk van Christus en van Israel uit.

\section{DIE AGTERGROND VAN VAN RULER SE SIENING}

Van Ruler se gedagtes oor die apostolaat moet in die groter raamwerk van sy teokratiese teologie verstaan word. Vir Van Ruler gaan dit in sy teologie om die ryk van God. Vir hom omvat die ryk van God egter veel meer as net dít wat in die Skrif staan. Wat in die Bybel aangebied word, is nie die enigste gestalte van die ryk van God nie. Vir Van Ruler is die ryksgestaltes ook te vinde in die sinagoge, die volk, die staat Israel, die maatskappy, die kultuur, die staat by gekerstende volke, die hart, die gewete, 'de prediking en het sacrament, het ambt en de gemeente, de kerkorde, de liturgie en het dogma' (Van Ruler 1969:55). Die eenvoudigste omskrywing van Van Ruler (1969:63) se teokratiese benadering is te vinde in sy woorde dat God se ryk 'loopt de cultuur binnen en de maatschappij en de staat'. Sy teokratiese begrip is dus geheel en al omvattend, en betrek die kerk by die totaliteit van menslike bestaan.
Volgens Graafland (1995:53) wil Van Ruler met sy teokratiese begrip juis die verband aandui tussen die toepassing van die heil in die hart van die individu, en die groter wêreld en kultuur waarin die individu leef. Daarom gebruik Van Ruler dan ook die metafoor van die saaier. God saai deur die geskiedenis sy heil oorvloedig op die akker van die wêreld. Hierdie saad val egter op verskillende plekke, en neem verskillende vorme aan. Dit bring egter die vraag na vore na die verband tussen hierdie verskillende gestaltes, of in terme van sy metafoor die saailinge, of wat hy histories noem die 'spronge' van die Ryk van God deur die geskiedenis. Meer bepaald kan ons vra na die verwantskap tussen die twee 'spronge' of gestaltes van die ryk van God in die Ou Testament en in die Nuwe Testament.

Van Ruler raai die sendinggerigte Christelike Kerk aan om, met die oog op die konkrete verwerkliking van die Godsryk, na die gestaltes van die Ou Testament te gaan kyk. Wanneer Van Ruler in Deel I van sy Theologisch Werk (1969:134-144) skryf oor 'De betekenis van de Mozaïsche wet' (oorspronklik in 1947 geskryf), ken hy daaraan kerugmatiese, eksistensiële, funksionele en materiële betekenis toe. Onder materiële betekenis verstaan hy dan:

[d]at het met name de mozaïsche wet is, waaraan wij de grondlijnen en het materiaal hebben te ontlenen, wanneer het in de agressiviteit van de kersteningsarbeid er om gaat, de wereld christelijk in te richten: een 'christelijke' staat draagt uitgesproken oudtestamentische trekken.

(Van Ruler 1969:134)

Die algehele menslike bestaan, oftewel eksistensie, met sy huwelik, geslagtelikheid en eiendom, kom in die Tora voor. Wil die gemeenskap dus Christelik wees, moet hy die Mosaïese wet toepas en dit na sy lewe deurtrek. Dit is egter 'n 'pneumatieshistoriese handeling' (Van Ruler 1969:143); nie 'n letterlike kontinuiteit nie.

Om Van Ruler se gebruik van die Bybel in die ontwerp van sy teologie, en veral sy apostolaatsteologie, deegliker te bestudeer, is hoofstuk 2 van sy Theologisch Werk Deel I (1969:46-99) oor 'Methode en mogelijkheden van de dogmatiek, vergeleken met die van de exegese' (1969:46-99) (oorspronklik in 1968 geskryf) van belang. As dogmatikus wys hy daarop dat die Dogmatiek verder gaan as die eksegese, omdat die eksegese slegs met die Skrif besig is, maar die Dogmatiek in die tradisie en kontemporêre bewussyn veranker is. Dít beteken vir Van Ruler die volgende:

Men kan maximaal van de dogmaticus vragen, dat datgene wat hij biedt een schriftuurlijk karakter draagt, dat wil zeggen: mede gevoed en bepaald wordt door wat de Schrift ons aan gegevens, en woorden biedt.

(Van Ruler 1969:65)

Die dissipline van Bybelse Teologie is vir hom 'n samevatting van die resultate van eksegese (kyk Van Ruler 1969:73), en bied vir hom die gegewens wat die Skrif aanbied. Omdat die getuienis van die Bybelskrywers oor God se geskiedenis met sy volk vol teenstrydighede is, sal dit in die dogma saamgevat moet word 'om althans enig houvast te hebben voor haar prediking van God en zijn rijk' (Van Ruler 1969:56). Hy verwys na hierdie teenstrydighede as 'leerlijnen'.

In die 'openbaringsverhaal' (Van Ruler 1969:80) wat die Bybelskrywers aanbied, loop daar 'leerlyne' wat met die are in die liggaam vergelyk kan word. Sommige van hierdie are kan opswel en prominent word. 'n Mens moet egter onthou dat daar nog:

...[d]uizend andere aderen zijn, die rustig hun werk doen, maar door geen enkele omstandigheid opzwellen en daarom verborgen blijven. In de bijbelse theologie loopt men nu het gevaar, de aandacht helemaal te bepalen bij die min of meer toevallig dik geworden aderen en van de andere, de onzichtbare, geen flauw vermoeden te hebben.

(Van Ruler 1969:80) 
Ten spyte van hierdie waarskuwing, maak Van Ruler self egter ' $n$ baie bepaalde keuse vir die historiese materiaal wat die buitelyne van die 'openbaringsverhaal' uitstippel:

...[e]r werken belangrijke theologische gedachtengangen, niet alleen in sommige uitspraken, maar ook in de hele opzet van althans sommigen boeken, met name in die 'historische' van het Oude en het Nieuwe Testament.

(Van Ruler 1969:77)

Hy verwoord die verskeidenheid as 'divergerende mogelijkheden, de vele leertypen of 'theologieën', welke in de Schrift worden gevonden' (Van Ruler 1969:82). Hy gee selfs toe dat daar teenstrydighede is - selfs 'kolossale spanningen' (Van Ruler 1969:82)

Ook tussen Ou en Nuwe Testament is daar 'verscheidenheid tussen de diverse schrijvers, boeken en eventueel bronnen genoeg. Daar zijn we zo maar niet overheen' (Van Ruler 1969:8283). Die kanongestalte van die Bybel veronderstel egter dat daar een of ander eenheid tussen albei Testamente moet wees. Die Skrif is vir Van Ruler 'n eenheid - 'zij het een organische eenheid, waarin de dingen groeien, zodat er ook van voortgang -van de geschiedenis en van de openbaring - in de Schrift gesproken kan worden. Maar het is een echte eenheid' (Van Ruler 1969:91). 'n Mens kan veronderstel dat daar oral 'grondgedachten' aanwesig is wat op dié eenheid dui. ' $n$ Mens moet ook probeer om hierdie eenheid aan te toon. Dít moet jy doen deur 'de ene schriftplaats met de andere schrifplaats, vooral de duistere met de duidelijke, te verklaren. Men doet het ook door de ene schriftplaats met de andere gelijk te breien. Men harmoniseert naar vermogen' (Van Ruler 1969:91).

Van Ruler volg dus veral daardie historiese leerlyne in die Bybel wat in sy terme die openbaringsverhaal, uitstippel. Hy is bewus van verskillende leertipes of teologieë in die Skrif, maar gee opsigtelik by voorkeur aandag aan daardie 'are' wat sy teokratiese teologie voed. Hy is bereid om verskillende, en selfs teenstrydige, gedeeltes te harmonieer, maar dit is opvallend da dit deurgaans aan die hand van sy oorhoofse teologie van die ryk van God gedoen word. Om die apostolaat as die voortgang van God se ryk in reële aardse terme te skets, keer hy dikwels terug na die Ou Testament om die konkrete aard van die ryksgestalte vir die Christelike Kerk aan te dui. Sy ontvanklikheid vir ook ander ryksgestaltes, gekoppel aan sy missionale gerigtheid van die Christelike Kerk, toon sy voorkeur vir inklusiewe denke oor die kerk, en vir inligting wat die inklusiewe aard van die kerk staaf.

Dít bring ons by die vraag of hy nie die Ou Testament op 'n manier gebruik wat een van die 'bultende are' van die Ou Testament, naamlik ' $n$ eksklusiewe oriëntasie, ignoreer nie? Dit was immers ' $\mathrm{n}$ probleem wat ook in die Nuwe Testament voorkom, en wat' $\mathrm{n}$ hele ent pad geloop het om die oënskynlik inklusiewe oriëntasie van die vroeë Christelike Kerk te help profileer. Die verhouding tussen inklusiewe en eksklusiewe oriëntasie is steeds een van die faktore wat ' $n$ rol speel - selfs in die na-moderne Christelike Kerk. Kan die Ou Testament nie miskien méér tot die besinning oor die identiteit van die kerk bydra as wat Van Ruler se werk te kenne gee nie?

\section{OËNSKYNLIKE VOORKEUR VIR INKLUSIWITEIT IN DIE NUWE TESTAMENT}

Die debat tussen eksklusivisme en inklusivisme was ' $n$ prominente tema in die vroeë geskiedenis van die Tweede Tempel (516 vC-70 nC) sowel as in die tyd van die vroeë Christelike Kerk. Die oerkerk was in 'n stryd gewikkel om sy eie identiteit te midde van verskillende strominge en oorgeërfde sienswyses te ontwikkel. Hoewel die werklike toedrag van sake oneindig meer gekompliseerd was as wat ons uit die Nuwe Testament kan aflei, is die algemene siening dat die Tora-georiënteerde Joodse Christendom wat in Jerusalem gesetel was, 'n bepaalde partikularistiese soteriologie aangehang het, wat regstreeks in stryd was met die Pauliniese been van die Christelike Kerk, met sy inklusiewe, universele soteriologie (kyk Park 2003:76). Die sogenaamde Jerusalemfaksie het Jakobus nagevolg en ' $n$ partikularistiese standpunt teenoor die nie-Joodse Christene ingeneem. Enigiemand kon deel word van die kerk, mits hy hom volgens Joodse gebruike laat besny. Hierdie standpunt is tot selfs ná die Bar Kogba-opstande en Hadrianus se verbod op Jode se verblyf in Jerusalem (132-135 nC) gehuldig. Dit het egter teen die tweede eeu ná Christus uit die geskiedenis verdwyn. Die standpunt wat aan Paulus toegedig word, het begin oorheers. Dit het die Jerusalemstandpunt ál meer begin marginaliseer, en het uiteindelik die kern van die opkomende Katolieke Kerk begin word. In die loop van die geskiedenis het die naïewe aanname (kyk Park 2003:2,3) posgevat dat partikularisme uitsluitlik aan die Jodedom toegeskryf kan word, en inklusivisme aan die Christendom.

In die vroegste Christelike Kerk het partikularisme en inklusivisme sy aan sy in die kerk bestaan. Die vraagstuk oor nie-Jode (die 'heidene') se plek in die geloofsgemeenskap was ' $n$ Joodse vraagstuk wat reeds lank voor die Christendom bestaan het. Met die ontstaan van die Christendom as vertakking van die Judaïsme is hierdie vraagstuk uit Joodse konteks op die Christelike Kerk oorgeplant.

' $\mathrm{n}$ Aanduiding dat hierdie vraagstuk reeds van die vroegste Christendom af bestaan het, is te vinde in die bespiegeling oor die 'naaste' en die 'vreemdeling'. Powery (2008:134-144) wys in sy ondersoek daarop dat daar op agt plekke in die Nuwe Testament na die gebod van Levitikus 19:18 (om jou naaste lief te hê soos jouself) verwys word, naamlik in Markus 12:31; Matteus 5:43, 19:19 en 22:39; Lukas 10:27; Romeine 13:9; Galate 5:14, en Jakobus 2:8. In die Matteus-evangelie word die aanhaling met Jesus verbind; in die oudste evangelie van Markus kom dit slegs een keer voor; in Lukas is dit die wetgeleerde wat dit aanhaal; Jakobus verwys een keer daarna, en Paulus verwys by twee geleenthede daarna. Ateek (2008:158-159) wys ook daarop dat dié gebod sosiologies begryp moet word. Vir harmonie in die gesin en die gemeenskap was dit noodsaaklik 'that people who were related maintain strong bonds of love towards each other. Such a practice ensured not only the peace but also the unity, solidarity, and strength of the community'. Dit was dus ' $n$ noodsaaklike houding vir die 'binnegroep'. Dit het egter nog nie die saak van die buitegroep, die 'ander', aangeroer nie.

Aan die ander kant verwys die Nuwe Testament nêrens na die opdrag van Levitikus 19:34, naamlik om die vreemdeling, die 'ander', lief te hê nie. Uit Hebreërs 11:13-16 kan 'n mens aflei dat die begrip teen die einde van die eerste eeu ná Christus gebruik is as 'a means of self-identification that both underscores the Christian community's present predicament and anticipates their eschatological hopes' (Powery 2008:143). Teen daardie tyd het die gedagte posgevat dat die vreemdeling 'een van ons' is.

Aan die hand van die begrip 'naaste' is dit dus duidelik dat daar meer as een standpunt oor hierdie saak was, en dat die denke oor die saak by sowel die binnegroep as die buitegroep ontwikkel het. Park (2003:ix) verwys na die twee standpunte as twee parallelle strominge: 'the gospel of the circumcision and the gospel of the uncircumcision', of ook die 'Torah-bound gospel' en die 'Torah-free gospel' (kyk Gal 2:7; Park 2003:2). Die twee standpunte was dit eens dat die verlossing van God die grondslag van die kerk is. Park (2003:2) merk soos volg op: 'Theologically as well as historically, both the gospels were still within the purview of Judaism.' Die verskilpunt het egter gekom by die vraag oor hoe mense as geloofsgemeenskap by God se genade betrek moet word. Moet inlywing in die groep plaasvind, of eerder uitbreiding van die gemeenskap na buite? Veral in die werksaamhede van Paulus het dit ' $n$ brandende teologiese vraagstuk in die jong kerk van die eerste eeu ná Christus begin word.

Volgens Park (2003:37) blyk dit uit Galasiërs 2:7 dat die konsilie van Jerusalem na albei kante toegegee het. Die evangelie van 
besnydenis en die universele soteriologie van nie-besnydenis is wedersyds erken, maar is wél aan verskillende arbeidsterreine toegeken. Petrus het die apostolaat van die besnedenes gekry, en Paulus uit Antiogië dié van hulle wat nie-Jode was en dus nie besny was nie.

Park (2003:28) herlei bogenoemde teenoorstaande standpunte na wat tradisioneel as die hoof- Joodse faksies van die laat laaste eeu voor Christus en die vroeë eerste eeu ná Christus beskou word. Die skool van Hillel was universeel gerig, terwyl dié van Sjammai eerder partikularisties ingestel was. Paulus se leermeester, Gamaliël, het tot eersgenoemde groep behoort. As sy leerling, was Paulus in die universele tradisie van Hillel geskool, wat op sý beurt op die tradisies van Deutero-Jesaja en Jona geskoei was. Dit het Paulus voorberei om universeel te werk; om teologies op die gebied van inklusivisme te werk. In die uitbreiding van die Christelike Kerk oor die bewoonde wêreld van daardie tyd heen, het hierdie rigting dan ook uiteindelik die toon vir die Christelike denke aangegee en ander standpunte oorwoeker.

\section{DIE OU TESTAMENT: EKSKLUSIEF SOWEL AS INKLUSIEF}

Soos hier bo opgemerk is, was die debat tussen eksklusivisme en inklusivisme 'n nalatenskap uit die vroeër tydperk van die Tweede Tempel. Die teenoorstaande standpunte is deur verskillende sosio-ekonomiese en teologiese faktore bepaal. $\mathrm{Na}$ afloop van die ballingskap het dit oor magsaanspraak op, en seggenskap oor, die tradisionele Judese gebied gegaan.

Net soos die begrip 'inklusivisme' in ons tyd met hedendaagse vraagstukke soos gender en multikulturalisme saamhang, moet in ag geneem word dat die konsepte 'inklusiwiteit' en 'eksklusiwiteit' destyds ook deur die omstandighede van die tyd bepaal is. Die konsepte 'eksklusivisme' en 'inklusivisme' het oor die algemeen met selfbeskouing in 'n bepaalde tyd en konteks te doen. Begrippe soos 'universalisme' en 'partikularisme' 'reflect two different ways of viewing oneself and others, which may apply to a far greater realm than religion' (Park 2003:9).

\section{Eksklusivisme in die Ou Testament}

In die tyd tussen die sesde eeu voor Christus en die oorname van gesag deur die Hasmoneërs in die middel van die tweede eeu voor Christus, was dit die Priesterhuis van Sadok wat in die aanvanklik Persiese en later Hellenistiese Juda die toon aangegee het. Hulle was verteenwoordigend van die Judeërs wat uit ballingskap teruggekeer het. In hulle magstryd met die Judeërs wat in die land agtergebly het, het hulle die oorhand gekry, hoofsaaklik met die steun van die Persiese owerheid, en later die alliansie met die Hellenistiese owerhede van die Ptolemeërs, en nóg later die Seleukiede. Grant-Henderson (2002:119) verwys hierna as 'a power struggle between groups who have different theological bases'. Uit die boeke 1 en 2 Makkabeërs kan afgelei word dat hulle eksklusiewe beleid tot diep in die Christelike era die dominante teologie in Juda was.

Die hoofnalatenskap van die Priesterhuis van Sadok is die tradisies wat met Esra en Nehemia, die Priestergeskrif en Kronieke vereenselwig word. Dit gee ' $n$ aanduiding van hulle veroordeling van mededingende groepe en ander sienswyses. Die Sadokities-geleide faksie het die oorlewingstrategieë gebruik wat hulle as minderheidsgroep in die ballingskap geleer het, hoe om sosiale en religieuse beheer oor hulle landgenote en bure te kry (kyk Boccaccini 2002:82). Hulle het 'n nuwe orde daargestel waarna almal in Juda hulle moes skik. Hulle het 'n nuwe Joodse identiteit gepropageer as dié van 'die kinders van die ballingskap' (Esra 4:1, 6:19-21 en 8:35). Dié wat nie aan die proses van tempelherstel en die nuwe bestel wou deelneem nie, is uitgesluit en uit die kultiese gemeenskap van Jerusalem verstoot.

Diegene wat nie in ballingskap was nie (die sogenaamde 'volk van die land' wat gedurende die ballingskap in die Judese gebied agtergebly het; kyk Esra 4:4-5 en 6:21), is nie net deelname aan die herbou van die tempel geweier nie, maar alle aansprake op gesag deur nakomelinge van die koningshuis van Dawid en die Levitiese priesters is boonop teengestaan. Die Sadokiete 'unceasingly and persistently defined the boundaries of cosmic and social structure; rules and regulations were enforced to restrict or control interaction and avoid trespassing' (Boccaccini 2002:73).

Die Sadokitiese partikularisme was niks nuuts nie. Reeds in die Dawidiese tyd én daarna was die teologie en politieke ideologie op partikularisme gegrond. Na gelang van of ' $n$ mens monoteïsme as 'n latere of 'n vroeë verskynsel beskou, kan Park (2003:12) se volgende standpunt van nut wees: 'The fundamental logic of Jewish particularism is based on monotheism and election, which were the two major features of Jewish theology.'

Hierdie 'logic of Jewish particularism' moet teen die agtergrond van die geskiedenis en die tradisie beskou word. Die spore van hierdie benadering is te vinde in die Priestergeskrif. Dit hou die skepping voor as 'n samehangende meganisme van 'graded holiness' (Boccaccini 2002:74), wat uit 'n ordelike en dig geslote hiërargie van lewende wesens, ruimtes en tye bestaan. Die grense daarvan mag nie oorskry word nie, omdat dit die balans sal versteur. Dit is ' $n$ geslote stelsel wat die onderbou vir ' $n$ sterk partikularistiese gerigtheid bied.

'n Ander dokument wat met hierdie gerigtheid verbind kan word, is Esegiël. Die politieke en religieuse program vir Sadokitiese beheer oor Juda word in Esegiël 40-48 vervat. Dit is ' $n$ dokument uit die tyd van die Babiloniese ballingskap. Die dokument stel 'n nuwe bestel in die vooruitsig, wat die Judaïsme voor-ballingskapse Judaïsme in ' $n$ algeheel nuwe rigting sou stuur. Die afstammelinge van die priester Sadok sou voortaan in beheer wees en die gestelde verwagtings ten uitvoer bring.

Die belangrikste dokument uit hierdie stal is die Esra-Nehemiaverhaal. Sowel die boek Esra as Nehemia eindig met die eksklusiewe afwysing van huwelike met nie-Judese persone. Die Sadokitiese beweging was gesteld op suiwerheid by die tempel sowel as in die gebruike van die volk. Soos die priesters suiwer moes bly deur nie te trou nie, is daar ook van die volk verwag om nie met persone buite die etniese groep te trou nie. Die priesters was die bewaarders van hierdie ideale, en het hulle self die gesag en beheer oor die volk toegeëien.

Wat in Esra-Nehemia gebeur, moet in die lig van omstandighede verstaan word. Soos soveel kere later in die geskiedenis met die Jode gebeur het, het die teruggekeerde Judeërs se oorlewing hier op die ongeskonde handhawing van hulle identiteit, die voortsetting van hulle geloof, en die ongehinderde aanbidding van God berus (kyk Grant-Henderson 2002:116). Uit 'n religieussosiologiese hoek kan die Sadokitiese maatreëls as 'n proses van kulturele heropbou ('cultural revitalization') beskou word (kyk Venter 1995:725-729). Die klein Joodse gemeenskap was ná die ballingskap ' $n$ provinsiale eenheid in die Persiese ryk wat as eiesoortige administratiewe eenheid beperkte politieke mag uitgeoefen het. Hulle was egter steeds aan Persiese oorheersing onderworpe. Hulle was in die klein gebied van Jerusalem en die provinsie Juda gevestig, en het hulle in 'n uiters delikate politieke situasie bevind. Hulle was gekonfronteer met die nasionale katastrofe van ekonomiese bankrotskap, en politieke onderhorigheid en belastingpligtigheid aan ' $\mathrm{n}$ vreemde moondheid in hulle eie land. Boonop was daar ' $n$ beduidende kulturele dissonans tussen hulle godsdienstige oortuigings en die omstandighede waarin hulle hulle bevind het. Vanweë die traumatiese ervaring van die ballingskap en die politieke omstandighede van die Persiese ryk, het ' $n$ bepaalde verandering in die aard van die gemeenskap en hulle selfbeskouing ingetree. Die leiers was terdeë bewus van die verlede van hierdie groep, en was bedag op die eise wat aan hulle as godsdiensgemeenskap gestel word. Die gemeenskap 
koester ideale van identiteitsbehoud, maar wil hulle identiteit terselfdertyd in hulle nuwe omstandighede in 'n nuwe rigting stuur. Hulle moes leer hoe om as onderhorige volk 'n godsdiensgemeenskap te wees. Die gemeenskap was steeds van hulle kulturele erfenis vervreem, en losgesny van hulle geestelike wortels. Onder hierdie omstandighede moes daar 'n kulturele transformasie plaasvind; ' $n$ radikale verandering van etos; ' $n$ herstel van waardes en simbole.

Wat belangrik was in hierdie transformasie, was die gemeenskap ná die ballingskap se vereenselwiging met die Israel van ouds. Die teenstrydigheid tussen oortuiging en omstandighede lê ook daarin dat die gemeenskap hulle nie voldoende met die vorige geslag vereenselwig nie, en nie besef dat hulle haglike omstandighede aan hulle eie ongehoorsaamheid aan die verordeninge van God te wyte is nie. Deur hulle opnuut aan God en sy gebooie toe te wy - deur hulle in solidariteit met die sonde van die voorgeslag in afhanklikheid voor God te stel word ' $n$ ou etos weer ingestel en in die nuwe omstandighede van politieke afhanklikheid heraktiveer (kyk die Skuldgebede in Esra 8 ; Neh 1 \& 8). Dit is ' $n$ tyd van kontinuïteit én diskontinuïteit. Die verwaarlosing van God se Wet het tot die katastrofe van Israel se ballingskap gelei. Die status van hulle unieke uitverkiesing as God se eie volk het in die spervuur beland. Die gemeenskap soek egter sy toekomsidentiteit in terme van die God met wie hulle voorheen in 'n verhouding gestaan het. Een manier waarop die gemeenskap hierdie verlangde identiteit kan herwin, is deur hulle met die Wet van God te vereenselwig. Noudat hulle terug is uit die ballingskap, moet daardie Wet weer die norm word, maar sal maatreëls ingestel moet word om die nakoming van die Wet moontlik te maak. Die nuwe (drastiese) maatreëls is daarop gemik om 'n sentrale begrip van die aard van die Joodse geloofsgemeenskap, van sy teologie, en van die betekenis van sy ryk en geskakeerde tradisies, aan te bied. Om die nakoming van die Wet te optimaliseer, beteken dat daar beheer moet wees oor die gemeenskap. Konkrete reëls oor huwelike en groepsvorming moet die nakoming van die wet in alledaagse bedrywighede verwerklik.

Park (2003:13) beskou die maatreëls as 'a resurgence of particularism'; 'n 'particularist policy' wat die werklikhede in Juda van die vyfde eeu voor Christus weerspieël. Dié wat agtergebly het en dié wat teruggekeer het, het verskillende politieke doelwitte gehad. Iemand moes leiding neem om politieke stabiliteit in die Persiese provinsie te bewerkstellig. Volgens Park (2003:13-14) het die groepe wat onder leiding van die Persies-gevolmagtigde leiers Esra en Nehemia teruggekeer het, ' $n$ besliste voorsprong op die Palestynse Jode gehad. Hulle partikularistiese beleid in die vorm van beheer oor die sluit van huwelike, was bedoel om beheer uit te oefen oor dié wat met die Samaritane gemeng het, en toon ' $n$ 'noticeable socio-political motivation' (Park 2003:14)

Die gedagte dat Israel verkies en geroep is tot heiligheid speel ook ' $n$ belangrike rol in hulle eksklusiewe identiteit. Die inhoud van hulle eksklusiwiteit kan egter nader bestudeer word in die voorskrifte van Levitikus oor die houding teenoor nie-Israeliete. Die opdrag van Levitikus 19:18 om jou naaste lief te hê soos jouself, moet saam met die begrip 'heiligheid' gelees word. Israel word as groep geroep om heilig te wees. In Levitikus is daar heeltyd ' $n$ beweging tussen kultiese reinheid en onreinheid. Die wette daarin is bedoel vir ' $n$ samelewing wat in die alledaagse wêreld leef, maar wat voortdurend in die teenwoordigheid van God staan. Die verband met heiligheid bepaal dus die bestaan van die groep. In die groep moet wedersydse liefde beoefen word. Hierdie liefde veronderstel egter nie, soos algemeen aanvaar word, 'n geneentheid teenoor alle mense voor die voet nie. Dié konsep word in Deuteronomium met Israel se begrip van die verbond met God verbind. Dit is sterk beïnvloed deur ou Naby-Oosterse verbondsterminologie. Dit is dus nie in die eerste plek 'n gevoelsaak nie, maar gaan eerder daaroor dat ' $n$ mens dit aan ' $n$ ander verskuldig is om hom reg en billik te behandel (wat ook die bedoeling is in Matt 18:15-20; kyk Kaminsky 2008:124-125). Die term 'volksgenoot' in Levitikus 19:17-18, en selfs die verwysing na die 'vreemdeling' ('resident alien') in
Levitikus 19:33-34, kan dus in die lig hiervan verstaan word. Hierdie 'ontvanklikheid' vir die nie-Israeliet wat onder die volk woon, hef nie sy vreemdelingskap op nie. Hoewel die Heiligheidswet (Lev 17-26) van die vreemdelinge vereis om bepaalde kultiese gebruike te eerbiedig, en hulle selfs toelaat om aan Israel se kultiese rites deel te neem, 'resident aliens remained distinct and are at some disadvantage' (Kaminsky 2008:124). Die voorskrifte waarborg dus hulle menseregte, maar hulle bly steeds 'resident aliens' sonder gelyke regte. Volgens Ateek (2008:159) bring Levitikus 19:33-34 die saak van die naaste in verband met die besit en bewoning van die land. Die billike behandeling van ander mense sluit ook die vreemdelinge in; hulle kan egter nooit ' $n$ gelyke aandeel in die besit van die land hê nie. Esegiël 47:21-23 gaan egter verder. Sowel Levitikus as Esegiël kom uit die tyd ná die ballingskap. Albei worstel met die probleem van die besit van die land. Met hulle terugkeer uit die ballingskap het die Judese ballinge met die probleem gesit dat die land nie leeg was nie, maar deur ander mense beset was. Omdat die land God se geskenk aan Israel was, het hulle dit as hulle eiendom beskou. Levitikus was bereid om hierdie ander mense wat die land beset het, as inwonende vreemdelinge te beskou, maar nie as mede-eienaars van die land nie. Ook Esegiël is oortuig dat dit Israel se land is, maar beoefen 'n meer pragmatiese etologie (kyk Ateek 2008:160). Op goddelike gesag verklaar hy dat die vreemdelinge wat al 'n geslag lank daar woon, saam met die stamme van Israel grond mag besit. Hulle moet as medeburgers beskou word.

Volgens Kaminsky (2008:127) het Israel se selfbeskouing as koninklike volk meegebring dat nie net die koning nie, maar alle lede van die volk hulle nou vir alle ander mense verantwoordelik geag het, selfs die randfigure van die samelewing.

While it may be tempting to label Israel's conception of itself as a priestly people distinct from other nations as a regressive and elitist notion, one must reckon with the fact that this very feature may have given birth to the Bible's unique insight that Israelites of all societal strata bore responsibility to create a just society in which those most marginalized were neither neglected nor abused.

(Kaminsky 2008:127)

Kaminsky stel die saak van eksklusivisme by Israel selfs verder in perspektief wanneer hy na 'n algemene wanvoorstelling verwys. Daar word onwillekeurig aanvaar dat Israel se unieke verkiesing vanselfsprekend alle nie-Israeliete/nie-Jode as vyande van God beskou het. Volgens Kaminsky (2008:130) is daar egter drie faksies ter sprake: dié wat verkies is, die 'anti-elect' en die 'nonelect'. Die 'anti-elect' is inderdaad daardie paar groepe, soos die Kanaäniete en die Amalekiete (kyk Deut 7 en 25:17-19), wat die vyande van God is wat deur die Israeliete uitgeroei moet word. Die meeste volkere word egter in die Hebreeuse Bybel as die 'non-elect' beskou: 'These non-elect peoples were always considered fully part of the divine economy, and, in a very real sense, Israel was to work out its destiny in relation to them, even if in separation from them' (Kaminsky 2008:131).

Nóg 'n siening van die kenmerkende partikularisme van Israel is te vinde in Strawn (1999:73-92) se beskouing van die begrip 'heiligheid'. Strawn (1999:75) sien heiligheid as 'n sentrale gedagte in die teologie van Israel, maar gaan van die standpunt uit dat 'the manifold ways that the concept of holiness is appropriated is diverse and dependent to a large degree on different geopolitical, sociological, and/or theological situations'. Daar is 'different appropriations or mentalities for holiness...limited, time-bound manifestations or mechanisms by which holiness is enacted and lived out' (Strawn 1999:75). Daar is 'n ooreenkoms maar tog ook 'n hemelsbreë verskil tussen die pogings tot selfhandhawing en ekonomiese stabiliteit by Esra-Nehemia, en die uitingsvorme van heiligheid by die Jesusgemeenskap. Strawn noem hierdie veranderlike uitingsvorme die ' $X$-faktor'. Dit het volgens hom altyd 'n kommunikatiewe bedoeling.

Heiligheid beteken in wese afgeskeidenheid. Dit kan baie vorme aanneem. Dit kan die vorm aanneem van die bonte 
verskeidenheid wette in Levitikus, die blou tossels in Numeri, of die selibaatskap van Jeremia. Volgens Strawn is heiligheid altyd 'n kommunikatiewe strategie wat uitdagings stel en antwoorde op vorme van heiligheid ontlok. Die voorskrifte in die Heiligheidswet (Lev 19-26) bind die Israeliete saam as God se volk, wat Hom op elke denkbare manier dien. Die voorskrifte plaas hulle eenkant, en onderskei hulle van alle ander. Hulle is geroep om anders te wees. Die voortdurende herhaling van die frase 'Ek is die Here' wys daarop dat dít geen doel op sigself was nie, maar dat dit God moes bekend maak en op sy heiligheid wys. Ook op plekke soos Deuteronomium 6:20-25, Esegiël 24:15-27 en Jeremia 16:1-13, het ons volgens Strawn (1999:79) te doen met voorskrifte met 'a sociological function that is communicative, perhaps one might even say missiological if not evangelical'. Volgens die beginsel van 'transgenerational value communication' (Strawn 1999:79), is die vereiste van heiligheid as afgeskeidenheid ' $n$ kommunikatiewe strategie wat juis vrae uitlok. Strawn (1999:79) gaan selfs so ver as om te dink dat die kommunikatiewe funksie van hierdie voorskrifte vir heiligheid en afskeiding 'part and parcel of the divine economy and plan' was.

In die tyd van die Tweede Tempel het nadenke oor identiteit ' $n$ ver pad in Juda geloop. Identiteit is veral aan die hand van die verhouding met ander groepe bepaal. Daar was ' $n$ volle spektrum van menings oor hierdie saak. Dit was ' $n$ punt van ideologiese konflik tussen teokrasie en eskatologie; tussen universalisme en eksklusivisme. Die spanning tussen die standpunte het al hoe meer geword, en selfs uiterste vorme begin aanneem. 'n Voorbeeld van die uiterstes van partikularisme is die boek Jubileë uit die middel van die tweede eeu voor Christus. Die outeur(s) was in dialoog met die Mosestradisie (Mosaïese of Sadokitiese Judaïsme) sowel as die apokaliptiese tradisie. Soos in die Makkabeërboeke, was hier ook 'n opsigtelike verskuiwing na 'n uitdruklik eksklusiewe monoteïsme (kyk Venter 2003:981988).

Die bedreiging waarteen die outeur van Jubileë sy groep waarsku, is aanslae van sowel binne as buite. Van buite doen volke wat as 'Kanaäniete' en 'Filistyne' beskryf word, die groep fisiese skade aan deur hulle aan te rand, dood te maak en te verdruk. Die grootste bedreiging kom egter van binne op kultureel-religieuse vlak. Dit kom in die vorm van die onderlinge alliansies waarby ander volke die lede van die groep wil betrek. Hierdie verbintenisse het veral te doen met onderlinge seksuele verkeer en huwelike tussen die volke. Hulle wil oor die afgebakende grense heen verhoudings smee. Sulke verbintenisse is nadelig en in die hemel self verbied. Dit bring besoedeling, en moet ten alle koste vermy word. Daar moet selfs nie eens onderhandelings daaroor aangevoor word nie.

In Jubileë 8-9 herskryf die outeur die volkeretafel in Genesis 10. Hy gebruik geografies-etnologiese tradisies, sy heptadiese kronologiese skema, en die gedagte van afgemerkte heilige ruimte, om die skeiding tussen die sogenaamde 'suiwer uitgekiesde geslag' en die 'onreine heidene' polities-religieus aan te dui. Dit beteken vir hom ' $n$ absolute skeiding tussen die afstammelinge van Set-Noag-Gam en die res. Afgebakende grense en uitgemerkte areas word aangedui wat die ware Israel van alle ander mense moet afsonder, en huwelike met ander geheel en al moet verbied. In hierdie fisiese skeiding kan die identiteit van die Judeërs gevind word. Geografiese inrigting en die konsepte van ruimte en tyd word hier gebruik om die gemeenskap en hulle identiteit te beheer. Die driehoek van kronologie, identiteit en ruimtelikheid vorm hier die matriks van eksklusiewe identiteit (kyk Venter 2008:649).

Hierdie eksklusiewe benadering was wél die dominante ideologie in die tyd van die Tweede Tempel in Juda, maar nie die enigste nie. Dit was in stryd met die benadering van minderheidsgroepe wat nie oor dieselfde magsbasis as die Sadokiete beskik het nie.

\section{Inklusivisme in die Ou Testament}

Die Ou Testament gee ook inklusiewe tendense weer. Die werkshipotese wat Grant-Henderson (2002:xx) vir inklusiwiteit gebruik, is:

[t] hat the offer of salvation is to all people, who if they choose to respond will receive the same benefits and responsibilites as the Israelites and who will be included in the worshiping community.

(Henderson 2002:xx)

In gedeeltes soos Eksodus 23:9, Levitikus 19:33-34 en Deuteronomium 23:8 word voorskrifte vir die hantering van die vreemdeling en bywoner gegee. Volgens hierdie gedeeltes mag hulle bepaalde voorregte tussen die Judeërs geniet, maar word hulle volle sosiale voorregte en deelname aan die godsdiens ontsê. In 1 Konings 8:44-47 word verklaar dat God die gebede van nie-Israeliete sal verhoor. Hoewel die boek Jona nie uitdruklik oor nie-Judeërs gaan nie, maar oor 'n ongehoorsame profeet as simbool van Israel, beeld dit God se genade uit vir dié wat nie tot Israel behoort nie. In Jesaja 19 en 25 word God se universele mag oor alle volke uitgebeeld. In Trito-Jesaja (Jes 56-66) en in Rut word nie-Judeërs op grond van God se reg en geregtigheid as ten volle deel van die godsdiensgemeenskap aanvaar.

Hoewel ‘n inklusiewe gerigtheid eers ná die ballingskap duidelik na vore kom, het dit reeds ' $n$ lang geskiedenis in Israel gehad. Park (2003:14) reken dat daar in die Ou Testament 'a continuing voice of universalism' is. Hy sien dit veral in die na-eksiliese boeke Rut en Jona. Lindeque (2001:101) sê dat boeke soos 'Rut, Jona, Job, Prediker, Ester, Judit en Tobit is geskryf vanuit die standpunt van die vroom lede van die inklusiewe groep en kan onderskei word van die nasionale geskiedenis, wette en profesieë wat deur die eksklusiewe groep versamel is'. Hierby sluit hy ook die eerste deel van die boek Daniël (Dan 1-6) sowel as die hele Josefverhaal (Gen 37-50) in.

In die eerste hoofstukke van Genesis is God die Skepper van die kosmos, maar ook van alle mense. Dit is eers van hoofstuk 12 af dat Abraham en sy nageslag van die res van die mensdom onderskei word, maar dan ook as die mense in wie al die volke van die aarde geseën sal word (Gen 12:3). God bly altyd die universele God, wat nasies gebruik om sy volk te straf, maar deur wie Hy hulle ook laat red.

Deutero- en Trito-Jesaja is die duidelikste voorbeelde van hierdie gerigtheid. Met die verdwyning van die monargie, en die sentralisering van die kultus deur die Sadokiete, het die profete van die toneel begin verdwyn. Die sosiale en politieke infrastruktuur vir hulle bestaan was daarmee heen. Hoewel hulle as sosiale klas verdwyn het, het hulle boodskap tog nog voortbestaan:

In the early Second Temple period, Third Isaiah and Ruth still testify to the vitality of the prophetic movement faithful to the heritage of the Davidic monarchy, and to their opposition against Zadokite exclusiveness.

(Boccaccini 2002:88)

Die Sionsteologie het, in teenstelling met die eksklusiewe Sadokitiese teologie, die nalatenskap van die Dawidryk verwoord in die verwagting oor Sion en die messias wat universele bevryding sal bring.

Deutero-Jesaja (Jes 40-55) bring ' $n$ wending in die tradisionele verkiesingsgedagte. Volgens hierdie anonieme profeet se gedagtes oor Israel se verkiesing, is hulle nie verkies sodat net hulle gered kon word nie, maar met die bedoeling dat hulle die instrument sou wees waardeur al die nasies na God gebring kon word. Kaminsky koppel hierdie denke aan die rol wat hier aan die skepping toegeken word (Jes 40:28, 43:14-21, 45:5-8 en 1819). Volgens Kaminsky (2008:31) was dit die teks van DeuteroJesaja 'along with certain late texts from Trito-Isaiah that build upon Deutero-Isaiah's insights, [that] begins to make room for those who wish to join themselves to God's people (e.g., Isa 56 and 66)'. Die metafoor wat hier gebruik word, is die 'lig van die nasies' (Jes 42:6 en 49:6). Hierdie uitdrukking het die sentrale simbool geword vir universalisme in sowel die Judaïsme as die 
latere Christendom. Hierdie standpunt is regstreeks in stryd met die Sadokitiese partikularisme. Volgens Park (2003:13) was dit 'the beginning of the tension between particularism and universalism in the history of Jewish thought'. Hoewel GrantHenderson (2002) saamstem dat daar verwantskap tussen Deutero- en Trito-Jesaja is, tref sy tog 'n onderskeid. Die status van die nasies in Deutero- en Trito-Jesaja verskil. Vir haar gebruik Jesaja $40-55$ eerder ' $n$ vorm van nasionalisme as universalisme. Dit gaan vir die profeet oor die herstel van die volk Israel. Die nasies se reaksie wys hier op die mag en eer van God. Volgens Grant-Henderson (2002:76) het geen gedeelte van Deutero-Jesaja 'a concept of coequality for the nations and the Israelites, and most times the status of the nations is quite vague'. Só tref sy dus 'n onderskeid tussen universalisme en inklusivisme wat van belang is vir hierdie studie.

Trito-Jesaja (Jes 56-66) word met ' $n$ voorwoord in Jesaja 56:1-8 en 'n slotwoord in Jesaja 66:17-24 omraam. Grant-Henderson vind in hierdie twee randgedeeltes die sentrale gedagtes van die hele Trito-Jesaja. Dit is 'n eenheidswerk, 'created as a unity with the express purpose of advocating the inclusion of foreigners over and against the proclamations of Ezra/Nehemiah and Ezekiel' (Grant-Henderson 2002:1). Dit is 'a considered apologetic on behalf of a group of people who accepts and includes foreigners within their community' (Grant-Henderson 2002:59). Hulle was besonder goedgesind teenoor die mense wat na afloop van die ballingskap die Judese gebied uit die omringende nasies binnegedring het, en was selfs bereid om hulle as deel van die gemeenskap te aanvaar en boonop met hulle te trou. Hulle gaan selfs so ver as om vreemdelinge as priesters en Leviete te aanvaar. Hierdie standpunt bring hulle natuurlik regstreeks in stryd met die ideale van Esegiël en Esra-Nehemia, wat suiwerheid bepleit en totale eksklusivisme ten opsigte van nie-Judeërs voorstaan. Die boodskap van Trito-Jesaja sou dus godslasterlik wees in die oë van die Sadokitiese priesters. Grant-Henderson (2002:31) verwoord dit selfs sterker: 'They are a group that not only contends with the strong words of Ezekiel and Nehemiah, but also has the Torah against them (Lev 26:14-45; Deut 23:1-8).

Baie min inligting is beskikbaar oor die mense wat ná die wegvoerings van 598, 587 en $582 \mathrm{vC}$ in die Judese gebied agtergebly het. Kultiese bedrywighede het rondom die vernietigde tempel en ander plekke voortgegaan. Hierin het priesters van ' $n$ laer orde as dié wat weggevoer is, 'n leidende rol gespeel. Dít het toegeefliker toepassing van wette tot gevolg gehad, veral wanneer mense van die omliggende omgewing hulle in die Judese gebied vestig en deel van die gemeenskap begin word (kyk Grant-Henderson 2002:32). Hierdie indringing het vreemdelinge en ontmandes ingesluit - iets waarteen die Esra-Nehemia-beweging ten sterkste in opstand gekom het. Die voorwoord in Jesaja 56:1-8 is in lynregte teenstelling met die heersende opvatting oor die Wet. God se reg en geregtigheid word hier na alle mense uitgebrei wat die Sabbat en die verbond onderhou. Selfs aan die ontmandes word hoop gebied. Elkeen wat gelowig is, maak deel uit van die geloofsgemeenskap:

The writer of Isaiah 56-66 had to call on an ethic of righteousness and faithfulness to make a claim for these people to remain within the community. Thus, although the Law might have condemned them, if people lived instead under the righteousness of God and followed that principle, then foreigners and eunuchs were to be treated in the same way as Israelites in the community.

(Grant-Henderson 2002:140)

Jona hoort volgens Boccaccini (2002:103) saam met die boeke Agikar, Spreuke en Job tot die beweging wat hy 'Sapiental Judaism' noem. Hierdie wysheidsbeweging het die verbondsmonisme van die Sadokitiese Judaïsme teengestaan. In Jona word die verbondsteologie nie ontken nie, maar word 'God's freedom to use unexpectedly the covenant as God likes' beklemtoon (Boccaccini 2002:110). Volgens Park (2003:16) toon Jona invloede van Deutero-Jesaja. Verskillende dele van die Nuwe Testament verwys byvoorbeeld daarna. Park dink dat die boek met die finale redaksie van Kronieke saamval.
Wat belangrik is van die boek, is die rol wat dit in die debat tussen universalisme en partikularisme speel. Grant-Henderson (2002:106) merk op dat Jona nêrens uitdruklik na Esra-Nehemia verwys nie, maar the message contained within it certainly confronts the actions proclaimed against foreigners in Ezra/ Nehemiah'. Die outeur van Jona is uitgesproke ten gunste van inklusivisme. Sy hoofkarakter is 'a caricature of a Jewish particularist' (Park 2003:14). Vir Park (2003:16) toon die boek:

[t]hat, just as Nehemiah and Ezra advocated an exclusivist and particularist ethos in trying to reconstruct the Jewish nation/ religion with the temple as its center and the Torah as its constitution, there were wisdom teachers whose horizon was more international and universalistic.

(Park 2003:16)

Waar Jona die vryheid en universele mag van Jahwe verkondig, wys die boek Rut hoe Dawid se Moabitiese voorouer in die Judese gemeenskap aanvaar is (kyk Grant-Henderson 2002:107). Anders as in Jona en Ester, waar dit Judeërs is wat hulle in die vreemde bevind, gaan Rut oor ' $n$ vreemdeling wat haar tussen die Judeërs bevind - wat moontlik met die situasie in Jesaja 56-66 ooreenstem, veral in die lig van die gemeenskaplike gebruik van die Hebreeuse term $n k r y$ vir vreemdelinge. In TritoJesaja word die vreemdeling op grond van God se geregtigheid aanvaar, al word hy tradisioneel deur die Tora weggewys. Rut is ' $n$ Moabiet wat met die Israeliet Boas in die huwelik tree en aan haar Israelitiese skoonma, Naomi, 'n nageslag besorg, onder wie Dawid ook later tel. Sy word in die Israelitiese gemeenskap aanvaar vanweë haar bereidheid om in die God van Israel te glo en Hom ook as haar God te aanvaar. Rut en Trito-Jesaja is ook die enigste gedeeltes in die Ou Testament wat uitdruklik oor die inklusiewe status van vreemdelinge in die Judese gemeenskap gaan.

Volgens Grant-Henderson (2002:91) word Rut gewoonlik volgens een van drie benaderinge gelees: '[a]s an apologetic against Ezra/Nehemiah around 400 B.C.E.'; as ondersteuning van die Leviraatshuwelik in ' $n$ tyd toe dit bevraagteken is; of as lofrede op Rut se inlywing in die Judese gemeenskap vanweë haar geloofsvoorbeeld. In watter tyd die verhaal ook al geskryf is, dink Grant-Henderson dat dit die tradisie van Dawid se Moabitiese oumagrootjie weergee. Dit is daarop gemik om diegene wat teen die aanvaarding van nie-Judeërs gekant is, aan hulle groot koning se afkoms te herinner: 'If David's ancestor was a Moabite and faithful, surely it is acceptable in the fourth century B.C.E. to marry a foreigner who is faithful to $\mathrm{YHWH}^{\prime}$ (Grant-Henderson 2002:97).

Daar is geen uitdruklike afwysing van die verbintenis met Moabiete in die boek Rut nie. Esra en Nehemia was egter uitdruklik gekant teen sulke verbintenisse. In Jeremia 48 se uitsprake oor die nasies word die Moabiete baie duidelik verdoem. Wat Rut indirek verkondig, druis dus regstreeks teen die algemene opvattings van die Tora in. Grant-Henderson (2002:98) se verklaring is dat' $n$ mens moet oorweeg 'what might be the social situation which prevailed in which a book was originally intended and the later canonical situation when it was accepted into the canon'.

' $n$ Inklusiewe gerigtheid is ook in ander dele van die Hebreeuse Bybel te vinde. Daar is enersyds ' $n$ aanduiding daarvan in die manier waarop Israel homself verstaan het, en andersyds in boeke wat nie ooglopend inklusief is nie. In die waardering van nie-Israeliete, soos die Farao se dogter (Eks 2:5-10), Job, Rut, die matrose saam met Jona op die skip, en Moses se skoonpa, Jetro (Eks 18), is dit duidelik dat ook húlle plek het in Israel se denke, maar dit is 'intimately bound to Israel's conception of how God lovingly interacts with the world' (Kaminsky 2008:131). Israel het ook nie hulle uitverkiesing as iets beskou wat ten koste van ander gebeur het nie, maar eerder iets wat ter wille van die res plaasgevind het. Israel se verstaan van partikularisme het ook ruimte gelaat vir die toetrede van nie-Israeliete tot hulle geledere deur besnydenis (Eks 12:48-49). Selfs die vreemdeling moes as 
' $n$ inwoner van die land beskou word (Eks 12:48). Raymann (2005:23) se verklaring van Eksodus 19:4-6 is dat 'heilige volk' beteken dat Israel 'a display people, a showcase to the world of how being in covenant with Yahweh changes a people' is. Die rede vir Israel se bestaan as volk is dat hulle ' $n$ instrument moet wees van die Missio Dei voor ander nasies. Israel se bestaansrede kan dus beskryf word as 'bo ander nasies, ter wille van ander nasies'. Isarel bestaan dus tussen al die nader nasies, maar sy bestaan is daar ter wille van hulle.

Ook Bybelboeke soos Josua en Numeri toon kenmerke van inklusivisme. Douglas se kommentaar van 1993 op die boek Numeri (In the Wilderness: The Doctrine of Defilement in the Book of Numbers) verbind die boek met die omstandighede in Israel ná die Babiloniese ballingskap. Die boek verkondig inklusiwiteit ter ondersteuning van diegene wat in Jerusalem agtergebly het en wat voor die bedreiging van marginalisering te staan kom. In ' $\mathrm{n}$ bespreking van haar boek, herhaal Douglas (1996:69) die gedagte dat die boek Numeri as '...a tract against the government's exclusionary policies...' geskryf is. Die Persiesgevolmagtigde leiers het volgens die inhoud van Esra en Nehemia etniese suiwering en suiwer afkoms voorgestaan. As die boek Numeri se literêre kunstigheid en die herskrywing van die reinheidsreëls daarin in ag geneem word, kom Douglas tot die volgende gevolgtrekking: ' $[\mathrm{T}]$ he priests were legislating for a plural society' (Douglas 1996:69). Sy verbind dit ook met Deutero-Jesaja: 'Their law book could support Isaiah's prophecy that all the nations will be proud to serve the Lord in Jerusalem (Isaiah 49.22; 66.18-21)' (Douglas 1996:69).

In sy doktorale tesis oor die boek Josua, kom Lindeque (2001:6477) tot die gevolgtrekking dat daar ' $n$ opvallende ooreenkoms is tussen die boeke Josua en Trito-Jesaja. Hierdie bevinding lei hom tot die gevolgtrekking dat Josua, net soos Trito-Jesaja, teen die agtergrond van die tyd ná die ballingskap (vanaf die Persiese tot die Hellenistiese tyd) gelees kan word. Die ballinge wat teruggekeer het, het hulle met die steun van die Persiese owerheid en die Sadokitiese priesters 'vir die herbou van die tempel en die herstel van die Dawidiese koningskap' beywer (Lindeque 2001:83). In die proses het hulle ' $n$ eksklusiewe denkrigting gevolg. Teenoor hulle staan dié deel van die bevolking wat nie in ballingskap weggevoer was nie. Hulle het samewerkingsbande met die omliggende volke gesmee, en het gevolglik ' $n$ inklusiewe denkrigting gevolg. Hulle het van ' $n$ bepaalde teokratiese standpunt uitgegaan.

Volgens Lindeque blyk hierdie strydigheid tussen inklusiewe en eksklusiewe denkrigtings uit die kenmerkende spanning in die boek Josua tussen ideaal en werklikheid ten opsigte van leierskap, volk, land, wetsonderhouding en verhouding met die nasies: 'Die ideale van die eksklusiewe denkrigting word as onbereikbaar en onrealisties voorgestel, terwyl die standpunt van die inklusiewe denkrigting deur die Josua-vertelling gelegitimeer word' (Lindeque 2001:85). In Josua word hierdie strydigheid in verband gebring met die onderskeid wat daar getref word tussen stamme wat hulle grondgebied aan die oostekant van die Jordaanrivier ontvang het, en dié wat aan die westekant grond gekry het (wat op die Hasmoniese tyd dui). Josua word ook met die Levitiese priesters verbind. Hulle was die teenstanders van die Sadokitiese priesters wat ná die ballingskap in alliansie met groepe gestaan het wat ' $n$ eksklusiewe standpunt aanhang. In die boek Josua, daarenteen, word buitestanders, soos Ragab en haar familie en die Gibeoniete, tegemoetgekom. Die eenheid van die volk word in Josua beklemtoon. Jerusalem funksioneer ook (vanselfsprekend) nie as kultiese sentrum in Josua nie - wél ander kultiese sentra, soos Gilgal, Ebal, Silo en Sigem. Dit alles dui vir Lindeque daarop dat die boek eers sy finale vorm in die tyd ná die ballingskap, bepaald die laat Persiese tyd, gekry het. In hierdie tyd het die ou Sionsteologie in die eksklusiewe standpunt herleef dat die gemeenskap van Jerusalem die werklike volk van God is. Alle ander groepe is gemarginaliseer - ook die mede-Israeliete wat nie in ballingskap weggevoer is nie. Teenoor hierdie eksklusiewe standpunt, soos dit in Esra-
Nehemia voorkom, was daar die alternatiewe inklusiewe siening dat almal deel is van God se volk, soos dit in Deutero- en TritoJesaja, Jona en Rut voorkom. Ook Josua was deel van hierdie alternatiewe inklusiewe siening. Lindeque (2001:115) kom dan ook tot die gevolgtrekking dat die boek Josua in sy finale vorm 'as ' $n$ kontranarratief op die eksklusivistiese standpunte van die na-eksiliese Sionsteologie beskou kan word'. Dit was in stryd met die eksklusiwiteit van die destydse Sionsteologie, en het die desentralisasie van godsdienstige gesag voorgestaan. Die belangegroep wat vir hierdie kontranarratief verantwoordelik was, 'was dus waarskynlik 'n gemarginaliseerde, na-eksiliese profetegroep wat in konflik met die godsdienstige elite van die Jerusalemse tempel verkeer het' (Lindeque 2001:117).

\section{SAMEVATTING EN SLOTOPMERKINGS}

In die besinning oor die kerk se identiteit, en sy verhouding met ander wat nie tot die kerk behoort nie, het sake soos apostolaat en missionaat ter sprake gekom. Dít skakel met sake soos inklusivisme en eksklusivisme. Omdat Van Ruler hom ook oor apostolaat in sy teologiebeoefening uitgelaat het, en dit in die breër verband van sy besinning oor die Koninkryk van God beskou het, is hy as aanknopingspunt vir die besinning oor inklusivisme en eksklusivisme gebruik. Van Ruler se teokratiese benadering beskou die kerk as die instrument waardeur God sy Ryk in die wêreld vestig. Vir Van Ruler (kyk 1969:63) loop God se Ryk 'de cultuur binnen en de maatschappij en de staat'. As instrument van God se ryk, is die kerk gevolglik op die wêreld gerig. Dit is in wese ' $n$ apostolêre gemeenskap wat in die wêreld ingaan.

Omdat God se Ryk met spronge deur die wêreldgeskiedenis beweeg, sal die kerk in sy menslike konkrete gestalte ook verskillende vorme in verskillende tye en omgewings aanneem. Vir Van Ruler het die kerk ook ' $n$ institutêre karakter. Terwyl dit op die wêreld gerig is, en in diens van God se Ryk in die wêreld funksioneer, sal dit te midde van die verskeidenheid van die wêreld ook 'n eiesoortige, binnekerklike karakter toon. Naas die oorhoofse inklusiewe aard van die kerk, is daar dus terselfdertyd ook 'n gekwalifiseerde eksklusiwiteit ter sprake.

Die moontlike vorme wat die kerk kan aanneem, is legio. In die Bybelse raamwerk merk Van Ruler ' $n$ pneumaties-historiese ooreenkoms tussen Israel en die Christelike Kerk. Die Christelike Kerk toon opsigtelike Ou-Testamentiese trekke. Van Ruler keer ook dikwels terug na die Ou Testament om die konkrete aard van die ryksgestalte van die Christelike Kerk aan te dui. Omdat hy as dogmatikus met 'n openbaringshistoriese grondmodel werk, stel hy veral belang in die historiese materiaal van die Ou Testament, wat die leerlyne of 'grondgedachten' van die 'openbaringsverhaal' uitstippel. Hoewel hy deeglik bewus is van verskillende leertipes of teologieë in die Skrif, gee hy opsigtelik voorkeur aan daardie 'are' wat sy teokratiese teologie voed. Hy gebruik die Ou Testament hoofsaaklik aan die hand van sy oorhoofse teologie van die Ryk van God, en gee vanuit sy inklusiewe denke oor die kerk voorkeur aan inligting wat die inklusiewe aard van die kerk staaf. Dít het dus ' $n$ studie van die ander perspektiewe wat in sowel die Nuwe as die Ou Testament voorkom, genoodsaak.

Dit is duidelik dat partikularisme en inklusivisme sy aan sy in die vroegste Christelike Kerk bestaan het. Dit was 'n baie ou vraagstuk wat reeds lank voor die Christendom in die Jodedom voorgekom het. Met die ontstaan van die Christendom as vertakking van die Judaïsme, is hierdie vraagstuk uit Joodse konteks op die Christelike Kerk oorgeplant. Selfs in die Nuwe Testament is vroue en slawe nie as volwaardige lede van die aanbiddingsgemeenskap aanvaar nie. Die sosiaal-teologiese debat oor die begrip 'naaste' het in die eerste eeu ná Christus telkens opgeduik. Dit was eers teen die tweede eeu ná Christus dat Pauliniese inklusiwiteit die dominante benadering in die Christelike Kerk geword het - deels vanweë die universele uitbreiding van die Christelike Kerk. 
Die stryd tussen eksklusiwiteit en inklusiwiteit was hoofsaaklik 'n erflating van die gemeenskap van die Tweede Tempel (516 $\mathrm{vC}-70 \mathrm{nC}$ ). Maatskaplike faktore en teologiese tradisie het telkens ' $n$ bepaalde rol gespeel.

In 'n tyd van heropbou ná die terugkeer uit die ballingskap, was dit die Sadokitiese Priesterhuis wat die mag in die hand gehad het. In hulle soeke na 'n nuwe identiteit vir die Judeërs wat teruggekeer het, het hulle volgens die program van Esegiël 40-48 'n stelsel van heiligheid met 'n sterk partikularistiese strekking uitgewerk, wat almal wat nie met hulle ideologie saamgestem het nie, gemarginaliseer het. Hulle denke is geboekstaaf in die tradisies wat met Esra en Nehemia, die Priestergeskrif en Kronieke vereenselwig word. Hierdie eksklusiewe denke is veral geopenbaar in die rigiede maatreëls oor huwelike, om te bepaal wie deel van die gemeenskap mag word, en wie nie. Die pseudepigrafiese boek Jubileë getuig van die voortsetting van hierdie eksklusiewe beweging

Die ervaring van dié wat gedurende die ballingskap in Juda agtergebly het, en met infiltrerende nie-Judeërs moes leer saamleef, het tot ' $n$ uitgesproke inklusiewe benadering gelei. Dit was 'n voortsetting van 'n universele Godsbegrip wat God as Heer oor alle volke gesien het, en wat by Israel tot ' $n$ omskrewe dog tegemoetkomende houding teenoor die vreemdeling in sy midde gelei het. Terwyl die boeke Jona en Deutero-Jesaja die universele mag van God beklemtoon wat ook ruimte vir die nieIsraeliet laat, is dit die boeke Rut en Trito-Jesaja wat uitdruklik vir die opname van nie-Judeërs in die godsdiensgemeenskap ruimte skep. Inklusiewe tendense kom ook in die na-ballingskapboeke Numeri en Josua voor.

Van Ruler se teokratiese benadering is van besondere waarde vir die herbesinning oor die identiteit van die kerk in ' $\mathrm{n}$ namoderne wêreld. In hierdie tydsgewrig sal die kerk nie anders as inklusief en apostolêr gerig op die wêreld kan bestaan nie. In die raamwerk van veral die Ou Testament sal die kerk egter ook 'n gekwalifiseerde eksklusiewe karakter moet hê. In diens van God en sy Ryk, en gerig op die eie tyd en die wêreld, sal dit ' $n$ kenmerkende, eiesoortige karakter moet aanneem, wat veranker is in sy belydenis dat Jesus Christus die Verlosser is van die wêreld. Aan die hand van Van Ruler se beeld (1978:58) sal dit 'een tent op de kermis van de leven' moet wees, waarin iets ervaar word wat nie elders bestaan nie.

In albei Testamente klink inklusiewe sowel as eksklusiewe stemmeop. Elkeen van hierdiestandpuntesal Bybelwetenskaplik, literêr-histories én tradisie-teologies beoordeel moet word om die huidige kerk van riglyne te voorsien. Grant-Henderson (2002:ix) waarsku teen 'an unreserved inclusivity'. Inklusiwiteit hou altyd voorregte sowel as bepaalde verantwoordelikhede in. Elke gemeenskap bepaal sy identiteit aan die hand van grenslyne en eie inhoud. In die Trito-Jesaja-materiaal word daar in die bepaalde omstandighede met die Tora-vereiste van Wet en etniese identiteit weggedoen, maar word daar onmiddellik weer op die nakoming van God se reg en geregtigheid aangedring deur die Sabbat te hou en aan die verbond getrou te bly. In teenstelling met ' $n$ rigiede eksklusivisme, sal die kerk hom vir 'n gekwalifiseerde inklusivisme moet beywer, wat op 'an ethic based on righteousness, justice and love' berus (GrantHenderson 2002:141)

\section{LITERATUURVERWYSINGS}

Ateek, N., 2008, 'Who Is My Neighbor?', Interpretation 62(2), 156-165.

Boccaccini, G., 2002, Roots of Rabbinic Judaism. An intellectual history, from Ezekeil to Daniel, Eerdmans, Grand Rapids.

Douglas, M., 1993, 'In the Wilderness: The Doctrine of Defilement in the Book of Numbers', JSOT, aanv. reeks 158.

Douglas, M., 1996, 'Review Colloquium, Introduction', Religion 1996(26), 69-89.
Graafland, C., 1995, 'Bevinding en cultuur bij A.A. van Ruler', in G. Klein \& D. Steenks (reds.), De waarheid is theocratisch - bijdragen tot de waardering van de theologische nalatenschap van Arnold Albert van Ruler, pp. 42-54, Callenbach, Baarn.

Grant-Henderson, A.L., 2002, Inclusive Voices in Post-Exilic Judah, The Liturgical Press, Collegeville, Minnesota.

Jongeneel, J.A.B., 1995, ‘De apostolaatstheologie van A.A. van RuIer, in contrast met die van J.C. Hoekendijk', in G. Klein \& D. Steenks (reds.), De waarheid is theocratisch-bijdragen tot de waardering van de theologische nalatenschap van Arnold Albert van Ruler, pp. 85-94, Callenbach, Baarn.

Kaminsky, J., 2008, 'Loving One's (Israelite) Neighbor: Election and Commandment in Leviticus 19', Interpretation 62(2), 123-132.

Klein, G. \& Steenks, D. (reds.), 1995, De waarheid is theocratischbijdragen tot de waardering van de theologische nalatenschap van Arnold Albert van Ruler, Callenbach, Baarn.

Lindeque, G.C., 2001, 'Die boek Josua gelees teen 'n na-eksiliese agtergrond', DD-proefskrif, Universiteit van Pretoria.

Park, E.C., 2003, Either Jew or gentile. Paul's Unfolding Theology of Inclusivity, John Knox, Louisville-Londen.

Plaisier, B., 1995, 'Enige gedachten over de actualiteit van de apostolaatstheologie van A.A. van RuIer', in G. Klein \& D. Steenks (reds.), De waarheid is theocratisch - bijdragen tot de waardering van de theologische nalatenschap van Arnold Albert van Ruler, pp. 76-84, Callenbach, Baarn.

Powery, E., 2008, 'Under the Gaze of the Empire: Who Is My Neighbor?', Interpretation 62(2), 134-144.

Raymann, A., 2005, 'The polarity between 'am and gôy for an understanding of "People of God" in the Old Testament', Theophilos Revista de Teologia e Filosofia - Ulbra: A Journal of Theology and Philosophy 5(1/2), Jan./Des. 2005, 3-28.

Strawn, B.A., 1999, 'The x-factor: Revisioning biblical holiness', The Asbury Theological Journal 54(2), Herfs, 73-92.

Van Ruler, A.A., 1953, Theologie van het Apostolaat, GF Callenbach, Nijkerk.

Van Ruler, A.A., 1969, Theologisch Werk Deel I, Callenbach, Nijkerk.

Van Ruler, A.A., 1978, 'De kerk is ook doel van zichzelf', in A.A. van Ruler, Verwachting en voltooiing: Een bundel theologische opstellen en voordrachten, pp. 53-66, Callenbach, Nijkerk.

Venter, P.M., 1995, 'Die aard van die geloofsgemeenskap in Nehemia 9', HTS Teologiese Studies/Theological Studies 51(3), 720-731.

Venter, P.M., 2003, 'Intertekstuele aanduidings van die wêreld van die boek Jubileë', HTS Teologiese Studies/Theological Studies 59(3), 957-989.

Venter, P.M., 2008, 'Space, time and group identity in Jubilees 8-9', HTS Teologiese Studies/Theological Studies 64(1), 631-650. 